\title{
Personal linguistic parametrization of text generation of the internet comments
}

\author{
Samal Z. Yergaliyeva - Natalia V. Melnik - Beibytnur K. Zhumabekova - \\ Kuanysh S. Yergaliyev - Nurlan R. Omarov
}

DOI: 10.18355/XL.2018.11.03.01

\begin{abstract}
The relevance of the research is determined by the interaction of a language and a man in the worldwide network and the increased influence of human communication on the linguistic activities. The objective of the research is to find out the level of personal and text generating of the Russian and Kazakhstani political Internet comments in the personal linguistic aspect. Methods of the research: collection and contextual analysis of the material, comparative-contrastive, descriptive methods and the method of quantitative estimation were applied in order to study this subject. The analysis performed was based on the parametrization of the political online comments. Moreover, the article deals with the human factors issue in the speech generating. Each generated text reflects a linguistic personality possessing a set of linguistic abilities governing the linguistic diversity and the variability of oral activity. The research outcomes showed that while generating the Russian Internet comments, the factor of personality conditioned by the parameters of the subjectivity of the linguistic persona predominates whilst the textual factors predominate in the Kazakhstani Internet comments. The significance of the study: the text generation parameters have been identified within the personal and textual strategies of text generation and the quantitative ratio of the personal and the textual has been determined in the Russian and Kazakhstani political Internet commentaries.

Key words: virtual linguistic identity, linguistic personal studies, Internet comments, parametrization, political discourse
\end{abstract}

\section{Introduction}

One of the characteristic features of modern linguistics is the study of the role of the human factor in the speech production. The development of computer networks, information and communication technologies and the subsequent expansion of human communication exerted an undoubted influence on the linguistic (more precisely, oral) sphere of human activity and contributed to the appearance of texts of different genres. The interaction of a language and a man in the worldwide network can be studied in various aspects since this interaction represents an interesting and almost inexhaustible subject of study for linguists, psychologists, sociologists, cultural specialists, psycholinguists, cultural linguists, etc.

The subject of our research is Russian and Kazakhstani political Internet comments to be one of the most common genres of network communication. The main purpose of the Internet comment is to express the author's opinion through the evaluation of certain facts coming to the forefront of social life. The content of the comment can concern any important event in economy, politics, science, and culture. The linguistic persona's mental and psychological features are well seen in the text of the comment. The initial hypothesis of the research is connected with the assumption that the factor of personality dominates in the generation of Russian Internet comments due to the different parameters of the linguistic persona's subjectivity, while the textual factor dominates in the Kazakhstani comments.

The purpose of the research is to find out the level of the parameters of the personal and textual text generation of the Russian and Kazakhstani political Internet comments in the personal linguistic aspect. 


\section{Literature Review}

A.A. Leontiev (2001) argues that the person questions himself to have answers to every problem that he is interested in, he observes and experiments because "when studying a person, we search all over and find signs and we try to understand their meaning" (Leontiev, 2001: 72). According to him, "a person is a process of a person's constant self-identification in the real world. This process drives cognitive activities, actions, experiences, etc. The person is primary in relation to the activity and consciousness" (Leontiev, 2001: 286). He believes that a person is not a fact of life but a quality formed as a result of the systematic activity which helps to mold a person's consciousness. K. Burke (1966) sees a language as a system of signs, and a man as "a sign using animal."

Later such statements became the basis for the formation of such a term as "a language personality," which, in its turn, was vigorously discussed by the scientists all over the world and to this day remains an important issue of linguistics.

Yu.N. Karaulov (2004) describes various approaches of the leading linguists to the understanding of a linguistic persona. For example, I.A. Baudouin de Courtenay considered a language personality to be "the receptacle of the social and linguistic forms and norms of the group of people," where the linguistic persona is the connecting link of different social and linguistic categories (cited by Karaulov, 2004). F.I. Buslaev (1992), approached this issue from the linguistic-didactic position making his methodological principles "in the unity of the native language with the learner's personality." Expanding the boundaries of studying the linguistic persona, V.V. Vinogradov chose the language of fiction in the individual creative work to be the subject of his study. He identified the linguistic persona through the image of the author and the artistic image (Karaulov, 2004).

G.I. Bogin $(1975 ; 1982)$ also considers the person in the linguistic and didactic aspect. First of all, stressing his/her speech abilities manifested in the texts, i.e. in oral activity productions, the author believes that the "arrangement of generation" is partially considered to be a person's speech capacity and produced by means of interverbal connections which mean firstly, storage of knowledge of linguistic means in one's memory and secondly, selection from the memory and retrieval of those linguistic means which are necessary for communication (text generation) (Bogin, 1975).

R. Rommetveit (1968) also believes that words are facts of the stimulus and the response, whose significance can be evaluated and identified in the psychological aspect. In this sense, he regards an oral ability to be one's readiness for intuitive actions.

J.B. Carroll (1968) correlates the speech ability with a habit as a "stimulus-response" mechanism, i.e., the body's response to a stimulus. However, B.F. Skinner (1953) believes that human behavior, speech behavior including, is controlled by the environment and is adverse to the fact that there is no human subjectivity between the stimulus and the response. In this respect, G.I. Bogin (1982) assumes that the social environment affects the role of human readiness to take part in the life of the society, motivating the person to develop further.

Yu.N. Karaulov (2004) considers the concept of "personality" as the result of social laws, the product of the nation's historical development and the motivational feature emerging when the biological impulses interact with the social and biological conditions and, of course, the personality is the creator and the producer of sign formations. Therefore, he believes that "there is a linguistic persona who owns the language system behind each text" (Karaulov, 2004).

According to N.D. Golev, N.V. Saikova, E.P. Khomich (2006) and E. V. Ivantsova (2010), the linguistic persona is the carrier of the language ability of a certain quality, inherent in him/her initially and further developing in accordance with the available

XLinguae, Volume 11, Issue 3, June 2018, ISSN 1337-8384, eISSN 2453-711X 
potential. In the opinion of A.R. Beisenbaev (2003), "there must be a person who is the author of the text in each utterance and in the whole text. The speech is impossible without the author because he produces the message and he is the subject of speech or the subject of evaluations".

According to linguists Z.I. Rezanova and Y.K. Skripko (2016), "the linguistic personality makes it possible to identify the cognitive and psychological identity of specific individuals, actualized by this discourse, to model the psychological features of the "average," typical personality of the discourse."

B. Johnstone (1996) considers the linguistic persona in sociolinguistic (class, gender, and race) and rhetorical (purpose and audience) aspects. She examines narratives of personal experience by a dying African-American woman and a middle-aged white man. In asking why the two stories are different. "Features of people's talk can be correlated with class or audience, the ways people talk about themselves have to do with the particular selves they are creating and expressing in the narrative. Individual variation thus has psychological roots".

A. D'Onofrio (2015) explores the effect of persona-based information on implicit linguistic perceptions of a sociolinguistic feature - the backed TRAP vowel. One group of listeners was told the speaker was from California, while another group was told that the speaker had been described as a Valley Girl. Findings demonstrate that both the California information and the Valley Girl information caused listeners to expect the speaker to exhibit TRAP-backing.

Having considered the above definitions, it can be concluded that there is a close relationship "a text - an author - a person - a linguistic persona - language abilities a mental image." This relationship is manifested in the fact that there is an author behind each text. An author is a person belonging to a certain stratum of the society; he is also a linguistic persona carrying inherent in him linguistic abilities which jointly make up his mental image. Therefore, we can say that language is not only a universal means of communication and exchange of thoughts between people, but also "reflects the culture, attitude, and thought patterns of a certain people" (Yergaliyev et al., 2015).

Scientists expanding the boundaries of the study of the linguistic persona concept began to study it in another light due to the emergence of new varieties of texts and genres where the relationship between the language and the man is investigated in a different perspective of the linguistic research. Development of information technologies (Crystal, 2001; Derakhshan, Hasanabbasi, 2015; Põlda, 2015; Mukwambo, 2016; Rai, 2017) has in particular contributed to the emergence of the Internet genres (Bets, 2012; Savelyeva, 2013; Yergaliyeva, Yergaliyev, 2017), an Internet comment being among them, which has drawn linguists' attention over the recent years.

According to Atef Odeh Abu Sa'aleek (2015), the Internet and the computer technologies have given rise to a new language undergoing a significant change in the written structure of the language - an electronic discourse. The author believes that the electronic discourse is like a half-speech between the conversation and writing, with its own characteristics and graphology. "It can be concluded that the communication via electronic communication media may facilitate the rise of a new variety of the language that is e-discourse and create new forms and functions of the language. Hence, researchers concur that the e-discourse has unique characteristics, which make it distinctive. A common appearance of its most frequent linguistic patterns would comprise shortening, clippings, and contractions, unconventional spellings, word-letter replacement, word-digits replacement, word combination, initialisms, and emoticons".

"In modern societies, the Internet encloses various possibilities of public communication and debate, by creating new spaces for political expression and participation. Citizens have therefore the opportunity for more active involvement in 
deliberation processes within a very different interaction framework from the one that is provided by conventional media" (Crystal, 2001).

D. Ivkovic (2013) deals with the language relationships expressed in the sections of the YouTube web pages. The subject of his study is the Internet comment in videodownloaded songs performed at the Eurovision contest. His research outcomes showed that singing in a non-native language is accompanied by mostly negative comments. In this regard, he says that "The YouTube online forums associated with the ESC have a large number of users from varied linguistic backgrounds who, because of their interests in song performance, are particularly attentive to languagerelated issues, such as the accent of the performers and the choice of language of the songs." Thus, D. Ivkovic's (2013) paper provides folklore and linguistic views on the languages and commentators' linguistic variations.

Most researchers believe that online comments differ from other types of comments by hypertextuality, interactivity, and synchronicity of communication.

D. Crystal (2001) highlights the hypertextuality to be the main characteristic of the World Wide Web.

Thus, the authors study a virtual linguistic persona, reconstructed in the political Internet comment which contributed to the investigation of the linguistic persona concept in another vein.

In one of the modern dictionaries - "The Online Big Encyclopedic Dictionary" (2000) - the following interpretation is given: "Comment (from the Latin commentariusnotes; interpretation). 1) book commentary (notes), explanations for the text, part of the scientific reference book. 2) In the system of mass media, it is a kind of operative analytical material explaining the meaning of the actual socio-political events, documents, etc." In the dictionary of T.F. Efremova (2018) the following interpretation is given: "To give a comment to any text. To explain, expound, interpret anything".

In the online resources of Merriam-Webster dictionary (2018) the interpretation of word "comment" is given: 1) a note explaining, illustrating, or criticizing the meaning of writing; 2) an observation or remark expressing an opinion or attitude; 3) a judgment expressed indirectly.

According to E.Ch. Dahalayeva (2013), Internet comments are micro-messages or reactions of the Internet user to the stated stimulus (news announcement, video, audio, image, etc.). The authors freely express their assessment of the motivating object (text, image, etc.) in these comments.

M.V. Bets (2012) defines the "virtual national language identity" studying it using linguistic-culturology and linguistic-personal views in the political discourse targeting the virtual national linguistic persona with the help of culturally significant concepts and keywords in the natural written speech which compares the frequency of lexeme use, axiological attitudes of the virtual linguistic persona implemented in the comments.

This concept is also found in the paper of I.V. Savelyeva (2013) who investigates variational strategies (holistic, elementary and the corresponding tactics) of text perception and text generation of a virtual linguistic persona in the online political comments. The authors of the present article cannot but agree with this opinion claiming that these strategies "are dependent upon the internal mental processes actively influencing the character of the text activity."

Investigating the linguistic persona in the virtual space, S.Zh. Yergaliyeva and K.S. Yergaliyev (2017) see it in terms of the linguistic-personal aspect. They focus on the production of the secondary text (an Internet comment) generated under the influence of personal and textual factors based on various parameters.

XLinguae, Volume 11, Issue 3, June 2018, ISSN 1337-8384, eISSN 2453-711X 
In the course of our research, the virtual linguistic persona is reconstructed on the basis of their political Internet comments which manifest the linguistic abilities in the mental and psychological aspect.

\section{Materials and Methods}

Materials for this study were based on the texts of Russian and Kazakhstani Internet commentaries which were left to the articles of political subjects located on the information portals Gazeta.ru, Politrussia.com, Segodnya.ru, Nur.kz, Newtimes.kz, Zakon.kz, Total.kz, Dixinews. Three hundred Kazakhstani and three hundred Russian Internet commentaries were collected and analyzed with the help of continuous sampling method. Each text - a comment - was compared with the initial source text, which became the motive for creating new secondary texts. The comparison was carried out in a formal, contextual and functional plan on the basis of the textualderivation analysis of initial texts which was developed by N.V. Melnik $(2010,2012$, 2014), and it helped to determine the personal and textual factors of text-generation in the Russian and Kazakhstani political Internet commentaries. At the next step, the method of introspection and contextual analysis of the texts was employed which contributed to the identification of text-generation parameters within the personal and textual factors. Clear differentiation of the personal parameters (associativity, irony, aggressiveness, conjecture, poeticness) and textual parameters (keywords, content copyability, form copyability, citation) of the text-based Internet commentaries to political articles was possible with the help of the quantitative calculation method. Also, the comparative method was used which enabled to confirm the research hypothesis that personal factor dominated in the text-generating of Russian Internet commentaries conditioned by the parameters of the subjectivity of the linguistic personality, while textual factors dominate in Kazakhstani Internet commentaries. The obtained conclusions of the study are reflected in the diagram (see figures 1,2).

\section{Results and Discussion}

The research outcomes showed that while generating the Russian Internet comments, the factor of personality conditioned by the parameters of the subjectivity of the linguistic persona predominates (tables no. 1, 2), whereas the textual factors predominate in the Kazakhstani Internet comments (tables no. 3, 4). The correctness/incorrectness of this hypothesis was verified using the linguistic analysis of the political Internet comments, the results of which are presented in the tables and figures below.

Table 1: Parameters of personal text generation of Russian Internet comments

\begin{tabular}{|l|c|c|}
\hline \multicolumn{1}{|c|}{ Parameters } & Quantity & Percentage \\
\hline Associativity & 11 & $3.6 \%$ \\
\hline Irony & 72 & $24 \%$ \\
\hline Aggressiveness & 59 & $19.6 \%$ \\
\hline Poeticness & - & - \\
\hline Conjecture & 38 & $12.6 \%$ \\
\hline Total & 180 & $59.8 \%$ \\
\hline
\end{tabular}

Table 2: Parameters of textual text generation of Russian Internet comments

\begin{tabular}{|l|c|c|}
\hline \multicolumn{1}{|c|}{ Parameters } & Quantity & Percentage \\
\hline Keywords & 45 & $15 \%$ \\
\hline Copyability of the content & 69 & $23 \%$ \\
\hline Copyability of the form & 1 & 0.33 \\
\hline Citation & 5 & $1.6 \%$ \\
\hline Total & 120 & $39.93 \%$ \\
\hline
\end{tabular}




\section{In total}

300

99.73

Table 3: Parameters of personal text generation of Kazakhstani Internet comments

\begin{tabular}{|l|c|c|}
\hline \multicolumn{1}{|c|}{ Parameters } & Quantity & Percentage \\
\hline Associativity & 1 & $0.33 \%$ \\
\hline Irony & 7 & $2.3 \%$ \\
\hline Aggressiveness & 4 & $1.3 \%$ \\
\hline Poeticness & 1 & $0.33 \%$ \\
\hline Conjecture & 45 & $15 \%$ \\
\hline Total & 58 & $19.26 \%$ \\
\hline
\end{tabular}

Table 4: Parameters of textual generation of Kazakhstani Internet comments

\begin{tabular}{|l|c|c|}
\hline \multicolumn{1}{|c|}{ Parameters } & Quantity & Percentage \\
\hline Keywords & 104 & $34.6 \%$ \\
\hline Copyability of the content & 127 & $42.3 \%$ \\
\hline Copyability of the form & 8 & $2.6 \%$ \\
\hline Citation & 3 & $1 \%$ \\
\hline Total & 242 & 80.5 \\
\hline In total & $\mathbf{3 0 0}$ & $\mathbf{9 9 . 7 6}$ \\
\hline
\end{tabular}

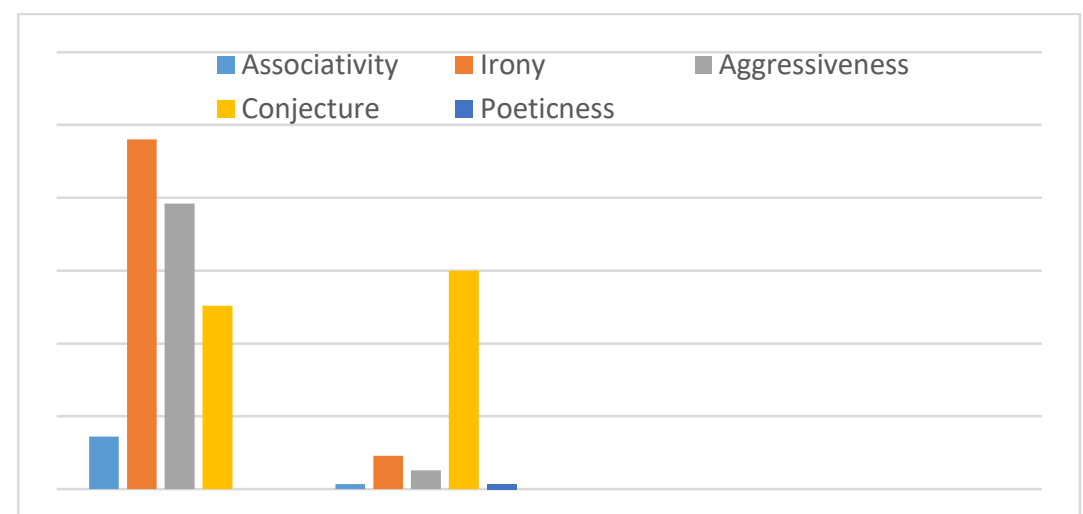

Figure 1: The quantitative criteria for the parameters of the personal text generation

Based on the presented figure 1, it can be determined that the level of personal text generation of political Internet commentary prevails in Russian texts, which is substantiated by different linguistic and extra-linguistic factors of text generation of a virtual linguistic personality.

XLinguae, Volume 11, Issue 3, June 2018, ISSN 1337-8384, eISSN 2453-711X 


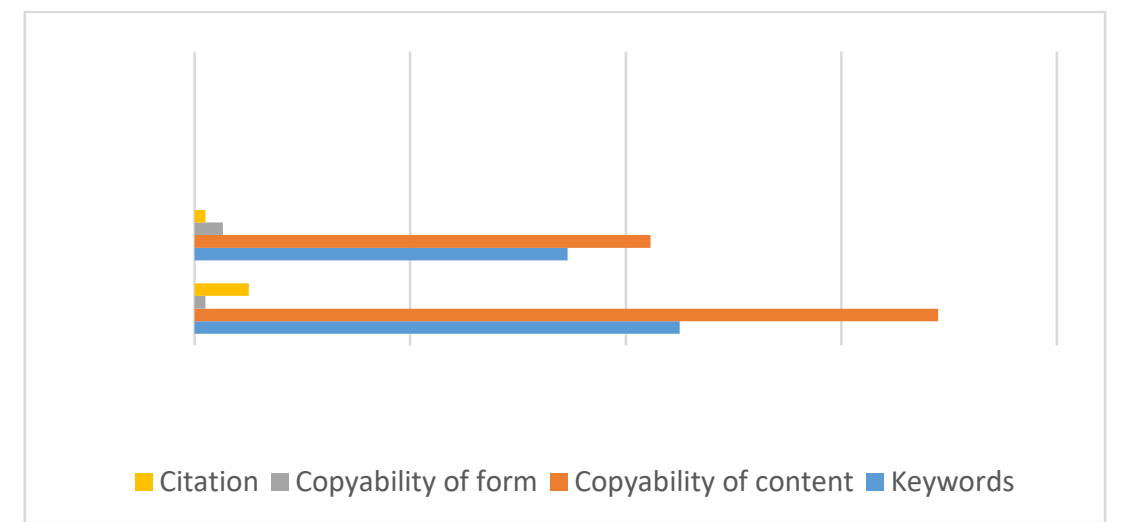

Figure 2: The quantitative measure of the textual parameters of the text generation

The results of the conducted research allow us to conclude that Kazakhstani Internet comments have a textual character, while Russian Internet comments have a personal nature, and it is directly related to the different quality of language ability of native speakers.

The research was conducted in the framework of text-derivative analysis of derived texts, suggesting the study of secondary texts in formal, informative, functional plans. The developed methodology made it possible to identify the personal and textual factors of text generation of the Russian and Kazakhstani political Internet comments. In the course of the study, the following parameters of the personal and textual text generation were identified:

- the main parameters of the personality of speech generation are associativity, irony, aggressiveness, conjecture, poeticness;

- the parameters of textuality - keywords, copyability of content, copyability of form, citation.

The developed parameters for the text generating of Internet commentaries helped to determine the linguo-personal potential of the political Internet- comments, which were taken from Russian Internet resources (gazeta.ru, politrussia.com) and from Kazakhstani Internet resources (nur.kz, today.kz). These portals contain the latest social and political news and publicist materials. Commentators of such portals are not just passive readers of the materials. Moreover, they become participants in the communication and reflect their ordinary political consciousness in their comments.

Let us define the parameters of the personal and textual text generation of the Internet comments.

Parameters of the personality of speech generating:

- the parameter of associativity. First of all, this tactic is connected with the mental and cognitive thinking of the person, since the language means which are chosen on this basis convey emotions or expressions of intention. Presented commentary clearly reflects a subjective attitude to the problem presented by the fact that the author uses associative tactics to describe key words. Let us consider the secondary text of the article "Krymskij golos Jerdogana" [Crimean voice of Erdogan] from the portal gazeta.ru: "A nu vstal i poshel golosovat'!” A mne Krym nuzhen $i$ nuzhen nedarom. "Nedarom pomnit vsja Rossija Pro den' Borodina!" Dazhe pro den' Borodina vse pomnjat ne darom... (Get up and go to vote! And I need Crimea and not without reason. "And all of Russia still remembers Borodino's Great Day!" Even about the Day of Borodino everyone remembers not for nothing...). In this commentary, the subjective-expressive feeling of the author is expressed more 
through associative utterances, which carries certain mental-conceptual information which is in the commentator's mind.

The next, let us analyze the Kazakhstani commentary on the article "Nazarbaev, Esimov, Golovkin i Nurtas voshli v spisok kandidatov ot Nur Otana" [Nazarbayev, Yessimov, Golovkin and Nurtas are included in the list of candidates from "Nur Otan"] from the news portal Dixinews: Uzhe shutjat $v$ Seti: Kajrat Nurtas kak ispolnitel' pesni "auyrmajdy zhurek" budet kurirovat' voprosy mediciny. Daesh' Sajlaubeka v Ministerstvo inostrannyh del! (There is already a joke on the web: Kairat Nurtas as a performer of the song "aurmaydi zhurek" will supervise the issues of medicine. Let us elect Sailaubek to the Ministry of Foreign Affairs!). Interpreting the initial text, the commentator singles out the singer-songwriter of the song "Aurmaydi zhurek" (translation - the heart does not hurt) Kairat Nurtas - and writes that it is better for him to go into the sphere of medicine. The text-comment is created with the help of the associative tactics of text generation, which is subjective (personal).

- parameter of irony. The parameter of irony is a frequently encountered parameter in the Internet commentaries, not only of a political nature and other ones. Since communicants communicate in distance, not contacting in live, especially anonymity, promoting free speech, removing tension and implementing a frank communication. In this parameter, communicants try to touch each other with obscene words, provoking aggressiveness.

This tactic is often found in the political discourse. The author with a sneer shows the attitude to the stated problem or to someone, for example: Da, chto vy govorite...slezy navernulis' na chele? Prjamo izoljacii-izoljacii (Yes, what are you saying ... tears have rolled on your face? What an isolation-isolation). As you can see, in this commentary the author with irony addresses one of the commentators, prompting him to aggression.

Here is a small fragment of comments to the article "Juzhnokorejskie vladel'cy fabrika "Rahat" obvinjajutsja $v$ hishhenii $i$ vzjatkah" [South Korean owners of the factory "Rakhat" are accused of embezzlement and bribery] from the portal zakon. kz. s kem povedjosh'sja, ot togo i zaberemeneesh'))); peredaetsja vozdushno-kapel'nym putem...; hahaha bystro adaptirovalis')))))); sposobnye ucheniki, legko obuchaemye... (with whom you will go from that, and you will become pregnant))); transmitted by airborne droplets ...; hahaha they quickly adapted))))))); capable pupils, easily trained...) As you can see, all of these comments reflect the mockery, the irony of the communicants, in which the connection with the source text is not visible. They are produced on the basis of subjective factors, that is, using the parameter of irony.

- the parameter of aggressiveness. Aggressiveness - like the tactics of irony, is often a tactic of political communication, which is manifested especially in Internet commentaries, because the commentator acts anonymously and can freely say what he thinks, therefore this tactic acts as a manifestation of subjectivity with a negative evaluation tint, for example: $S$ juridicheskoj tochki zrenija - katastrofa. Ruki organizatoram referenduma nuzhno otorvat'; TY BY, HOT" RAZ!!! O SVOEM, ROSSIJSKOM NARODE VSPOMNIL!!! A TO VSE PALESTINY, NEGRY I PROChEE $L U K O M O R^{\prime \prime} E$ (From a legal point of view, it is a disaster. The hands of the organizers of the referendum must be torn off; YOU NEED AT LEAST ONCE, ONLY ONCE THINK ABOUT YOUR PEOPLE, TO REMEMBER THE RUSSIAN PEOPLE!!! BUT ALL OF THESE PALESTINES, NEGROES AND OTHER LUKOMORYE).

Thepresented comments demonstrate a clearly manifested protest, dissatisfaction of communicants by the interlocutor's assessment of the political situation. This is expressed in the secondary text created by the author, which is presented in capital letters, repeated use of punctuation marks, which indicates the manifestation of his aggressively emotional state. He presents his text as the voice of the people, which is

XLinguae, Volume 11, Issue 3, June 2018, ISSN 1337-8384, eISSN 2453-711X 
a characteristic of everyday linguistic-political speech. Thus, it can be assumed that this tactic conveys the subjective characteristics of the text.

- the parameter of conjecture. The parameter of conjecture is explained by the fact that the commentator interprets the initial article, writing his own text on the basis of his own experience and information received, thereby unfolding the subject of the source text along a subjectively specified path.

The tactics of conjecture will be demonstrated in the next Russian commentary on the article "Krushenie bez imen" [The crash without names] of the news portal Gazeta.ru:Est' konechno $i$ takie, kto vidit dal'she svoego puza, ne sporju...Takie "pustjakovye" voprosy kak sostojanie jekonomiki strany, blagosostojanie ee grazhdan stalo interesovat' tol'ko durachkov vrode menja, nesposobnyh, kak vy verno zametili, "videt' nemnogo dal'she sobstvennogo puza"... (There are of course also those who see beyond their belly, I do not argue ... Such "trifling" issues as the state of the country's economy, the welfare of its citizens became interested only fools like me, unable, as you rightly noted, "to see a little further than your own belly" ...). Here it can be seen that the subjective conjecture of the problem is clearly manifested, the author goes beyond the primary text, complicating its content. He generates his own text; the primary text becomes for him only a stimulus, to which an expressiveemotional reaction follows, therefore this comment arises with the dominant influence of subjective factors.

A similar issue is observed in the Kazakhstani portals, for example, in the commentary to the article "Zhitelej Kazahstana zovut prijti na vybory" [Kazakhstani residents are invited to come to the polls]: Ne znaju kuda my pridem, nado stranu podnimat'! Molodezh' opasno stavit' na novye mesta ...im nuzhna praktika; hotja chto ja govorju, kak stradal prostoj narod, tak $i$ stradaet, neft' poslednjuju vykachajut $i$ budem sidet' u razbitogo koryta, posmotrite $k$ primeru na ZK, reki ushli pod zemlju, ozjora peresohli, Ural obmelel na net... (I do not know where we will come, we need to call out the country! It is very dangerous to elect young people in the new places ... they need practice; and what I am saying... how the common people are suffered, so they are still suffering, the oil is siphoned off, and we will sit at the broken trough, look for example at Western Kazakhstan, the rivers have gone underground, the lakes have dried up, the Urals has become shallow...). The commentator worries about the future of the country, presents his vision of the problem, beginning with the issue of elections and ending with problems of a global scale. As a result, he leaves out the content of the article both formally and informally; the source text serves only as a stimulus.

- the parameter of poeticness. This parameter differs from others by emotionality, poeticness, the creativity of the linguistic personality in the generating of secondary text. Let us present a comment to the original text "Kazahstancy shantazhirujut CIK, ugrozhaja ne prijti na vybory" [Kazakhstanis blackmailing the Center of Election Committee threatening not to come to the polls] from the news portal Dixinews:

uitel' zhizni prosto i ne slozhno,

do samoj, samoj uchit i krepis'

tomu, chemu nauchit ochen' vazhno,

uchit'sja tol'ko $v$ zhizni ne lenis'!

(the teacher teaches the life simply and easily,

to the utmost and insists that

what he teaches is very important,

you should not just be lazy to learn in your life!)

chto prezident ne dolzhen, ne soglasen

byl obrechjon doveriem ljudej

vot rezul'tat byvaaet ochen' vazhen,

ved' izbirat' drugogo byl ne smej!

(that the president should not, do not agree 
was doomed by people's trust

here the result is very important,

because you could not elect another one!)

As you can see, the author produces a comment in poetic form, expressing his value attitude through the creative, emotional vision of the political world.

Thus, when identifying and comparing the parameters of personal text generation of the Russian and Kazakhstani political Internet commentaries with the help of quantitative calculation, the level of these parameters was determined in Russian and Kazakhstani texts generating of the Internet commentaries, the results of which are presented in the figure.

The parameters of textuality in the text production are:

- the parameter of keywords. The presented tactics tend to objective factors, as the author uses key words from the source text, interpreting, thinking up it in his own way, but without departing from the theme of the motivating text, an example from the Kazakhstan article will be given on the topic "Zachem Nazarbaev priezzhal $v$ Almatinskuju oblast'?" [Why did Nazarbayev come to the Almaty Region?] (nur.kz): Oblast' bol'shaja, mnogo razlichnyh predprijatij v raznyh sferah, na kotoryh rabotajut ljudi $i$ sejchas vazhno, chtoby tam sohranjalis' rabochie mesta; razvitie agropromyshlennosti vsegda $v$ prioritete (The region is very large,there are many different enterprises in different spheres, where people work and it is significantly important now that jobs should remain there; the development of agro-industry is always a priority).According to the given comments, it can be seen that the sentences use keywords from the source text, for example oblast', predprijatija, rabotajut ljudi, razvitie agropromyshlennosti (the region, enterprises, people work, the development of agro-industry). They convey the content of the article, preserving the general meaning, the topic of the stated question. This parameter is directly considered as a parameter of objective text generation.

\section{- the parameter of copyability of the content.}

The parameter of copyability of the content is done by sending the content of the source text by the Internet commentators with the help of indirect deployment or reduction of thoughts, substitution of the keywords with synonyms or other linguistic (variational) means which are chosen by the virtual linguistic person during commenting on the political problem. Let us consider the comment on the article "Krushenie bez imen" [Crash without names] from the news portal Gazeta.ru: Zhitel' Pervomajskogo Vasilij soobshhil Business FM, chto ne videl: "Ne bylo, ja ne videl po krajnej mere, ne znaju”. Drugoj gorozhanin Artem rasskazal, chto takzhe ne nabljudal takoj kartiny: "Net, ja nichego podobnogo ne videl zdes' takogo". (The citizen of Pervomaisky, Vasily said to Business FM that he did not see anything:"There was nothing, I did not see, at least I do not know". Another citydweller Artyom said that he also did not observe such kind of picture: "No, I have not seen anything like this here"). This fragment of the message was not reflected in the source text, the author thought up the continuation of the situation himself. However, he thought up of it without departing from the content of the source text. The fragment he created has a textual nature because his conjecture is produced within the framework of this problem. The parameter of copyability of the content dominates in the commentary.

- the parameter of copyability of the form. The parameter of form copyability means copying a fragment or the whole primary text in an unmodified form and using it in the production of a secondary text. In the presented commentaries to the article "Kazahstancy shantazhirujut CIK, ugrozhaja ne prijti na vybory" [The Kazakhstani are blackmailing the CEC, threatening not to come to the elections] from the portal Dixinews, the author of the second text duplicates the text of the previous

XLinguae, Volume 11, Issue 3, June 2018, ISSN 1337-8384, eISSN 2453-711X 
communicant's comment. He completely copied previous text to his post without any change and without any addition.

Elena: Ubrat' voobshhe vseh deputatov i ostavit' prezidenta i pravitel'stvo, kotoroe on naznachaet $i$ kontroliruet. (Yelena:Blot out all deputies altogether and leave the president and the government which is appointed by him and it is under his control).

Gost': Ubrat' voobshe vseh deputatov i ostavit' prezidenta i pravitel'stvo, kotoroe on naznachaet $i$ kontroliruet. (Guest:Blot out all deputies altogether and leave the president and the government which is appointed by him and it is under his control). It can be suggested that such kind of action of the commentator works when he fully agrees with the previous one and supports his position. It can be made various assumptions about why he chose this method of text generation, and it is maybe a convenient way for him to convey his opinion. Here the commentator used the parameter of the form copyability by copying the microtext form.

Let us give one more commentary to this article, which was not produced on the texts of other communicants, but on the basis of the source text. For example vot jeto novosti. 1.5 milliona tenge. 4 milliarda (this is news. 1.5 million tenges. 4 billion). The author pays attention to the digital data and copies them in the form in which they are provided in the text. Therefore, the commentator used the parameter of the form copyability in order to generate his own text, which reflects the text potential of this comment.

Thus, during the text-derivational analysis, the peculiarities of using the parameter of the form copyability on the examples of the two countries were clarified. When comparing the text generating of Russian and Kazakhstani Internet comments on this parameter, it was noticed that Russian commentators duplicate fragments or parts of both source and texts of other communicants, and in Kazakhstani texts, it is often found complete copying of a whole secondary text, that is, a text-comment of the interlocutor.

- the parameter of citation. This parameter is implemented with the help of using citation tactics of the source text (macrotext or microtext). When quoting, the author copies a fragment of the source text or the text of the interlocutor without any modifications and uses it to express his own thoughts, intentions as an additional insert.

Let us consider one more example from the article "Sirija na grani nervnogo sryva" [Syria is on the verge of a nervous breakdown] where the author cites the fragment of the report stage by stage.

"Rossija $i$ SShA pereshli ot sirijskogo peremirija $k$ ugrozam razorvat" sotrudnichestvo" - net, Rossija, naoborot, za sotrudnichestvo, a ugrozy posypalis' ot SShA ("Russia and the United States have moved from the Syrian armistice to threats to break off cooperation" - no, Russia, on the contrary, for cooperation, and threats have come from the United States).

"Rossija i SShA 29 sentjabrja obmenjalis' rjadom zhestkih zajavlenij po povodu sirijskogo uregulirovanija" - net, Rossija voobshe nichego zhjostkogo ne govorila dazhe v otvet na ugrozy ot SShA ("Russia and the United States exchanged a series of tough statements about the Syrian settling on September 29" - No, Russia did not say anything tough even in response to threats from the United States).

This comment is produced on the basis of textual factors since it consists of quotations extracted from the article. The commentator leads two fragments from the source text without changing, and it means he quotes, and then also comments on how he sees the problem. His interpretation is of a textual nature because it uses the key words from the presented quotes in the primary text. Thus, this comment has a textual basis.

\section{Conclusions}

The text of the original political article has the potential of derivational functioning, 
implemented in the texts of Internet commentaries using variative strategies and tactics of text generation. The choice of the latter is determined by the peculiarities of the linguistic personality. Thus, the authors have identified the parameters of text generation within the personal and textual text generation strategies taking them as the basis for the classification of the parameters of the content, form, and function of the secondary text. The subjectivity index can be seen through the following parameters: associativity, irony, aggressiveness, conjecture, poeticness, while objectivity indicators through keywords, copyability of the content, copyability of the form and citation. These parameters, both of textual and personal character, act both in the Russian and Kazakhstani political Internet commentaries, but their quantitative ratio is different, since the listed factors of the text generation of the Internet commentaries directly depend on the linguistic and extra-linguistic factors of the virtual linguistic personality of political Internet commentaries, which reflects its ordinary linguistic consciousness.

The scientific novelty of the research is in determining the strategies and tactics which are realized by the linguistic personality of the commentator at the stages of text generation in the linguo-personal aspect; the study was conducted on the basis of texts compiled by ordinary native speakers who are not professionals in the field of politics, who left their feedback on the article in the form of online commentaries; this genre is studied on the basis of two languages belonging to different linguistic groups. The analysis results of the textual activity of the Internet commentator's linguistic personality make a contribution to linguistics branches, such as linguo-personal studies, linguo-politology, everyday linguistics and text theory, analysis of strategies and tactics which are used by the Russian and Kazakhstani virtual linguistic personalities who comment on the political articles.

The results fit into the system of linguo-personal and linguo-cultural research, conducted on the basis of written spontaneous speech activity of ordinary native speakers presented by two linguistic cultures. The research findings can be applied both in linguodidactics, in particular, in the teaching of philological and pedagogical disciplines, and in everyday communication, which requires this kind of knowledge for effective speech interaction.

\section{Bibliographic references}

ABU SA'ALEEK, A.O. 2015. Internet Linguistics: A Linguistic Analysis of Electronic Discourse as a New Variety of Language. In: International Journal of English Linguistics, vol. 5, no. 1, p. 135-145. ISSN 1923-869X

BEISENBAEV, A.R. 2003. Language Essence and Ways of Text Egocentrism Explicating. Author's abstract of PhD Thesis in Philology. Almaty.

BETS, M.V. 2012. Axiological Correlation of the Text of an Informational and Analytical Article and a Comment in the Runet Virtual Space. PhD Thesis in Philology. Kemerovo.

BOGIN, G.I. 1984. The Model of Linguistic Persona in its Relation to the Variety of Texts. Author's abstract of $\mathrm{PhD}$ Thesis in Philology. Available online: https://studfiles.net/preview/3299583/. 36 p.

BOGIN, G.I. 1986. Typology of understanding a text. Kalinin: KGPU Press. Available online: http://linguistics-online.narod.ru/index/0-240

BURKE, K. 1968. Language as Symbolic Action. Essays of Life, Literature and Method. Berkeley. Los Angeles: University of California Press. ISBN10: 0520001923.

BUSLAEV, F.I. 1992. Teaching of the native language. Moscow: Prosveshhenie. ISBN 5-09-004461-9. 
CARROLL, J.B. 1968. The Psychology of Language Testing. In Davies, A. (Ed.) Language Testing Symposium. Oxford: Oxford University Press. ISBN 978-0-19968203-4.

CRYSTAL, D. 2001. Language and the Internet. In: Cambridge University Press. ISBN: 9781139164771.

DAHALAYEVA, E.Ch. 2013. Internet comments of the portal "News mail.ru" as an object of linguistic research. Modern Problems of Science and Education, no. 6, pp. 73-86. Available online: https://www.science-education.ru/ru/article/view?id=11418

DERAKHSHAN, A. - HASANABBASI, S. 2015. Social Networks for Language Learning. In: Theory and Practice in Language Studies, vol. 5, no. 5, pp. 1090-1095. ISSN 1799-2591

D'ONOFRIO, A. 2015. Persona-based information shapes linguistic perception: Valley Girls and California vowels. In: Sociolinguistics, vol. 19, no. 2, pp. 241-256. ISSN: 13606441.

EFREMOVA, T.F. 2018. New Dictionary of the Russian Language. Available online: http: //www.efremova.info/word/kommentirovat.html

GOLEV, N.D. - SAIKOVA, N.V. - KHOMICH E.P. 2006. Linguistic Personology: Types of Linguistic Personas and Personality-oriented Training. Kemerovo: BGPU Press. ISBN: 5882103606.

IVANTSOVA, E.V. 2010. Linguopersonology: the fundamentals of the theory of a linguistic persona: a textbook. Tomsk: Tomsk State University Press. ISBN: 978-57511-1935-5.

IVKOVIC, D. 2013. The Eurovision Song Contest on YouTube: A Corpus-based Analysis of Language Attitudes. Cambridge: Cambridge University Press. ISSN 1860-2029

JOHNSTONE, B. 1996. The linguistic individual. Self-expression in language and linguistics. Oxford: Oxford University Press. ISBN: 0195101855.

KARAULOV, Yu.N. 2004. The Russian Language and the Linguistic Persona. Moscow: Editorial URSS. ISBN 5354003539.

LEONTIEV, A.A. 2001. Active Mind. Moscow: Smysl. ISBN 5-89357-106-1

MELNIK, N.V. 2010. Derivatological and Lingvopersonological interpretation of secondary texts. In: Bulletin of KemSU, n. 4, pp. 148-153. ISSN: 2078-8975

MELNIK, N.V. 2012. Derivatological interpretation of secondary texts of different types. In: Bulletin of the ChSU, vol. 13, n. 267, pp. 69-73. ISSN: 1994-2796

MELNIK, N.V. 2014. Derivation of the Russian text: Linguistic and Personological Aspects. Moscow: LENAND. ISBN: 978-5-9710-1303-7

MERRIAM-WEBSTER DICTIONARY. 2018. URL: https://www.merriamwebster.com/d-ictionary/comment.

MUKWAMBO, M. 2016. Trainee teachers' experiences using contextual teaching and learning: Implications for incorporation of indigenous knowledge in instructional design. In: Pedagogical Research, vol. 1, n. 1, pp. 3-12. Available online: https://doi.org/10.20897/lectito.201611. ISSN: 2468-4929 (Online).

PÕLDA, H. 2015. The Linguistic construction of the giftedness discourse in the media texts of historical and digital times. In: Eesti rakenduslingvistika ühingu aastaraamat, n. 11, pp. 223-239. ISSN 2228-0677

RAI, D. K. 2017. The Challenges of Spanish Language Teaching in Multilingual India: A Case Study of Delhi. In: Pedagogical Research, vol. 2, n, 2, 05. Available online: https://doi.org/10.20897/pr/80950. ISSN: 2468-4929 (Online).

REZANOVA, Z.I. - SKRIPKO, Y.K. 2016. Personality in the medium of discourse: linguistic representation of psychological types. In: Bulletin of the Tomsk State University. Philology, vol. 3, n. 41, pp. 37-56. ISSN: 1998-6645

ROMMETVEIT, R. 1968. Words, Meanings and Messages. Theory and Experiments in Psycholinguistics. New York: Routledge. ISBN-10: 0125946503; ISBN-13: 9780125946506. 
SAVELYEVA, I.V. 2013. Variability of Text Perception and Text Generation Strategies: a Linguo-personological Aspect. PhD Thesis in Philology. Kemerovo. Available online:

http://d01.kemsu.ru/Content/AdvertAttachedFiles/951ade074e61479c.pdf

SKINNER, B.F. 1953. Science and Human Behavior. New York: Routledge. ISBN: 9780029290408 .

The Online Big Encyclopedic Dictionary. 2000. Available online: http://www.onlinedics.ru/slovar/be-s/k/kommentarij.html

YERGALIYEV K.S. - ASSANBAYEVA Y.B. - AMRENOV A.D. SHAHARMAN G. 2015. Linguistic View of the World and Peculiar Features of its reflections in Newspaper Headlines. In: Mediterranean Journal of Social Sciences, vol. 6, no. 5, p. 264-268. ISSN 2039-9340/2039-2117.

YERGALIYEVA, S.ZH. - YERGALIYEV, K.S. 2017. Linguo-personological Potential of Political Internet Interpretations. In: Bulletin of the Eurasian Humanitarian Institute, Philology Series, n. 2, pp. 254-258.

Words: 6899

Characters: 46590 (25,88 standard pages)

Graduate student Samal Z. Yergaliyeva,

Translation Studies and Linguistics Department

Kemerovo State University

6 Krasnaya St., Kemerovo, 650043

Russia

samal.yergaliyeva@bk.ru

Assoc. Prof. Natalia V. Melnik, Doctor of Philology

Stylistics and Rhetoric Department

Kemerovo State University

6 Krasnaya St., Kemerovo, 650043

Russia

natalia.melnik.2019@inbox.ru

Assoc. Prof. Beibytnur K. Zhumabekova, PhD of Sciences (Philology)

Foreign Languages Department

S. Toraigyrov Pavlodar State University

64 Lomova St., Pavlodar, 140008

Kazakhstan

beibytnur.zhumabekova@bk.ru

Assoc. Prof. Kuanysh S. Yergaliyev, PhD of Sciences (Philology)

Kazakh Language and Literature Department

Pavlodar State Pedagogical University

60 Mira St., Pavlodar, 140000

Kazakhstan

kuanysh.yergaliyev@bk.ru

Assoc. Prof. Nurlan R. Omarov, PhD of Sciences (Philology)

Russian Language and Literature Department

Pavlodar State Pedagogical University

60 Mira St., Pavlodar, 140000

Kazakhstan

nurlomarov@yandex.ru

XLinguae, Volume 11, Issue 3, June 2018, ISSN 1337-8384, eISSN 2453-711X 